\title{
APPLICATION OF ELECTRICAL RESISTIVITY IMAGING AND LAND SURVEYING IN THE ANALYSIS OF UNDERGROUND CONSTRUCTION IMPACT ON THE WARSAW SCARP
}

\author{
Lukasz Kaczmarek ${ }^{1}$, Radosław Mieszkowski ${ }^{1}$, Marek Woźniak ${ }^{2}$, Tomasz Dybciak ${ }^{2}$ \\ ${ }^{1}$ University of Warsaw, Faculty of Geology, Al. Żwirki i Wigury 93, 02-089 Warszawa, Poland, \\ e-mails:lukasz.kaczmarek@uw.edu.pl,r.mieszkowski@uw.edu.pl \\ ${ }^{2}$ Warsaw University of Technology, Faculty of Geodesy and Cartography, Pl. Politechniki 1, \\ 00-661Warszawa,Poland, e-mails:m.wozniak@gik.pw.edu.pl,dybciaktomasz@gmail.com
}

\begin{abstract}
The paper presents the analysis of the II Underground Line construction's impact on the Warsaw Scarp with the use of the electrical resistivity imaging (ERI, also known as the electrical resistivity tomography) and further total station position measurements. The underground passes under the scarp perpendicular in the area of Dynasy Street 6, in Downtown district. The electrical resistivity imaging was performed for recognition of the geological structure and a potential landslide surface or zone. The gradient system was used during the prospection. In these analyses, the longitudinal section was $40 \mathrm{~m}$ long, and the depth of survey amounted to $6 \mathrm{~m}$. In the case of the $200 \mathrm{~m}$ long transverse section, the resulted depth of survey was $30 \mathrm{~m}$. The geophysical image of the longitudinal section, does not contain loosening soil zones, which could indicate slip surface. Next, total station measurements, which were tied to the archival geodetic observations' results, were carried out. The aim of the measurements was to verify the activity of the horizontal and vertical displacements. The TBM excavation process led to summary vertical displacements up to approx. $24 \mathrm{~mm}$ and horizontal displacements amounting to approx. $13 \mathrm{~mm}$. To sum up, the current land surveys reveals minor underground line's construction impact on the scarp displacement. Nevertheless, the sensitive urban environment requires further monitoring, especially that the operation loads can result in displacement rate change.
\end{abstract}

Key words: electrical resistivity imaging, position measurements, underground, Warsaw Scarp, displacements

Manuscript received 27 April 2016, accepted 26 October 2016

\section{INTRODUCTION}

The scarp stability as a state of forces equilibrium is changing over time (Duncan and Wright, 2005). The changes are determined by infrastructure, as well as, natural variability of soil and water-related conditions. One of the places where the magnitude of destabilizing forces and opposite to them forces has changed is the Warsaw Scarp in Powiśle district, due to the construction process of the 2nd underground line using Tunnel Boring Machines (TBM). The above mentioned location is a place of intersection of a communication line with Quaternary and Mio-Pliocene sediments. The construction of the underground in Warsaw is an example of a complex and large investment interfering in an urbanized area. In the past, such constructions caused risk to human lives and financial loss, e.g. the construction of W-Z road from which the displacement of the Warsaw Scarp originated. In that case, the ruins of the Royal Castle and the Church of Saint Anna were endangered. Another example worth noting is an archival case study of the Wisłostrada road damage, caused by the TBM work.
The City Center part of the Warsaw Scarp in the neighborhood of Powisle district is a very attractive place for investment, due to its landscape values. The geological condition of this area can be found in numerous papers (e.g. Wysokiński,1999; Sarnacka, 1992). The investment process which is the construction of the underground II line with the description of geodetic and geotechnical monitoring was presented in the executive project (ILF, 2010). The task of monitoring the movements has been developed on the basis of earlier scientific studies carried out on the behalf of Metro by Woźniak (2007). Details of the results of observations conducted during the underground construction were collected in the information system, which interface for data management and communication with the user was available in the form of a website (http://www.ddsmonitoring.com/index.php).

This paper presents recognition of the underground II line construction impact on the Warsaw Scarp by means of geophysical electrical resistance tomography, and use of surveys to support the correct interpretation of the final results. 


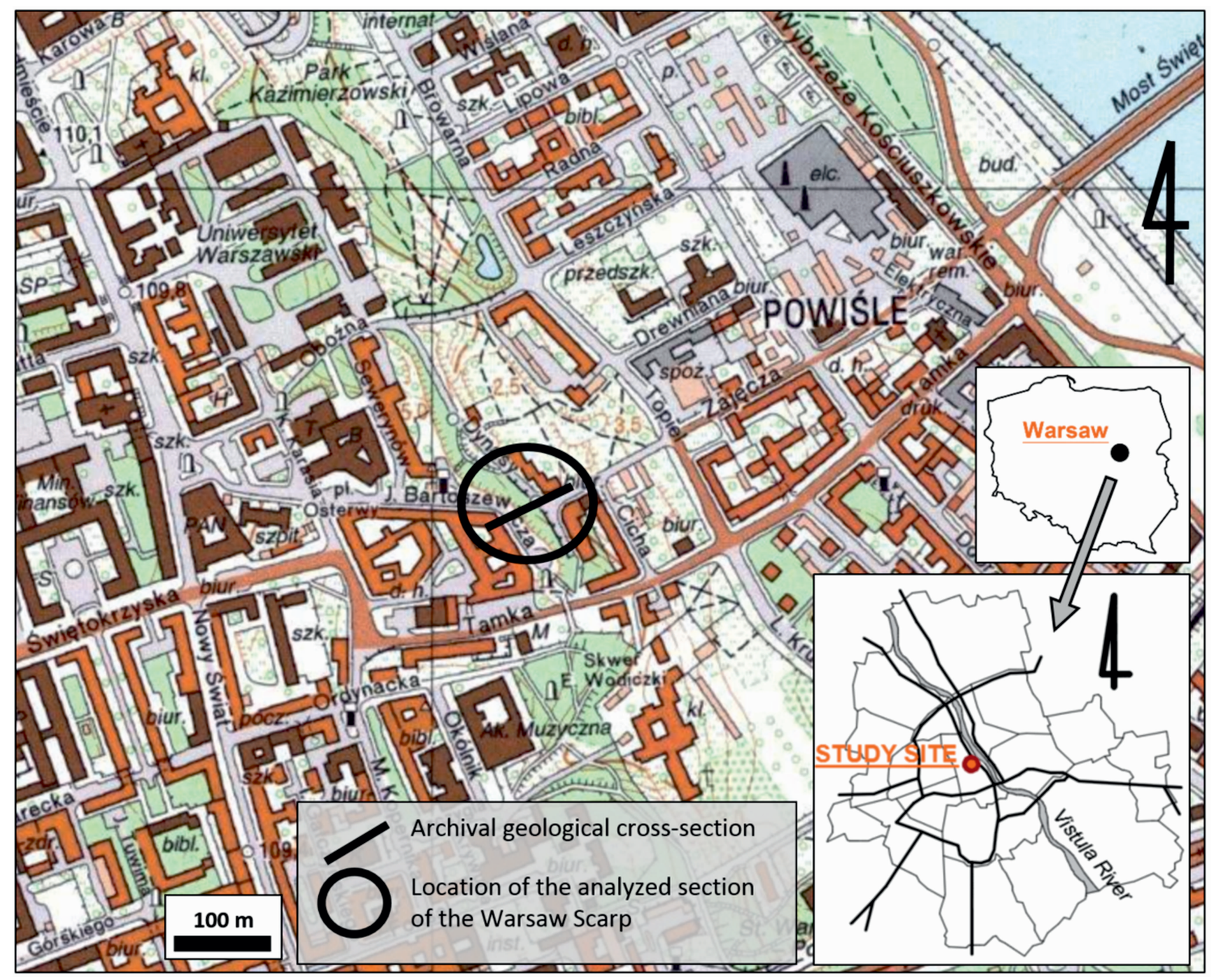

Fig. 1. The location of the analyzed section of the Warsaw Scarp on the topographic map (www.geoportal.gov.pl) as well as in the schematic map of Warsaw and Poland.

\section{REGIONAL SETTINGS}

The study area is located in the center of Warsaw, east part of Powiśle borough in Downtown district and covered a part of the Warsaw Scarp, under which passes the Warsaw Underground Line II (Fig. 1). Bartoszewicza Street runs along this part of the scarp, with Dynasy Street along its foot. The scarp height is approx. $17.5 \mathrm{~m}$ and inclination of the scarp is approx. $36^{\circ}$ in reference to geodetic measurements.

The geological structure of the Scarp consists of a complex system of deposits. The first layer which can be indicated in the Warsaw plateau and Vistula valley is madeground of about $3 \mathrm{~m}$ in thickness (Bajda and Falkowski, 2014). The crown of the scarp, under the fill, consists of tills from Warta glaciation (about 1-m-thick layer) and Odra glaciation (about 10.5-m-thick layer; Wysokiński, 1999). These two layers are interbedded by fluvioglacial medium sand (several meters in thickness). Near the surface of the scarp there is colluvium zone. Furthermore, below the tills in the crown of the scarp and valley deposits is a Mio-Pliocene clay layer. In the Vistula Valley, below the fill, there is a thin layer of fluvial silt and next underlies a thin layer of medium sand (fluvial deposits). Figure 2 shows a scheme of the geological structure (Wysokiński, 1999; 2013) and the location of the underground tunnel with the buildings in the Vistula valley.

The ground water level is approx. $14 \mathrm{~m}$ below terrain surface of the scarp crown and $4.7 \mathrm{~m}$ below ground level at the scarp toe (Wysokiński, 1999).

\section{METHODS}

The electrical resistivity imaging was performed for recognition of geological structure and a potential landslide surface or zone. In order to verify presence of the mass movements process expressed by the activity of the horizontal and vertical displacements, the available results of land surveying in the area were analyzed, and some additional measurements using high precision automatic total station were made providing details on the three coordinates of the controlled points. The inclination of the scarp and its height above underground line were additional results of geodetic surveying. 


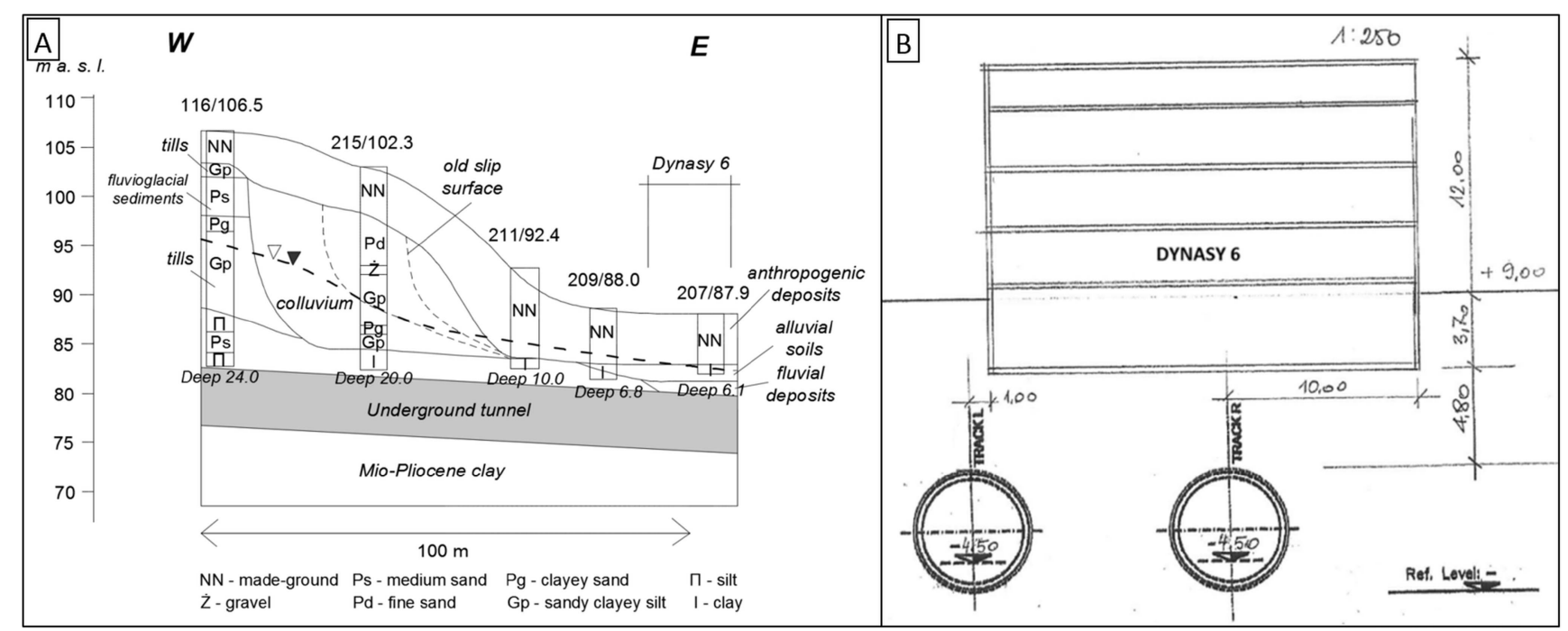

Fig. 2. Part of the archival geological cross-section (A) compared to the construction project (B; after Wysokiński, 1999; 2013).

\section{Electrical resistivity imaging}

The most popular geophysical techniques are electrical resistivity imaging, the seismic measurements (Tucholka et al., 2008) and the ground-penetrating radar (Welc et al., 2013 and Lejzerowicz et al., 2014). The electrical resistivity imaging (ERI) was chosen according to the prospection conditions and a large prospection range. Therefore, two electrical resistivity sections were measured for this area of the scarp; one in a direction along the underground tunnel, and the other in the transverse direction (Fig. 3).

The electrical resistivity imaging method for soil surveying was developed by the Schlumberger brothers in 1920 (Loke, 2000). As shown by many research results, this method enables a variety of interpretations regarding the characteristics of the studied soil. The ERI allows, among others, the identification of the landslide surface in the scarp (Perrone et al., 2014; Kowalczyk et al., 2014; Kaczmarek et al., 2015). This method uses the phenomenon of the flow of direct current through the soil for determining its physical characteristics based on the propagation of the electrical signal. The biggest advantage of the ERI is the possibility of obtaining a 2-D electrical cross-section along the studied profile. The theoretical basis of the ERI is described by Loke (2012). During the survey made along the entire length of the electrical resistivity section in a single process controlled by the measurement equipment, all the electrodes are arranged at an even distance from each other before the analyses begin. In these analyses, the longitudinal section was $40 \mathrm{~m}$ long, and the clearance between the individual electrodes equaled $1 \mathrm{~m}$, so that the surveying depth amounted to $6 \mathrm{~m}$. Such prospection, in the case of $\sim 17.5 \mathrm{~m}$ height scarp, is sufficient for detection of loosening zone of shallow slip surface. If the slip surface is located deeper, the terrain surface geodetic measurements will indicate the risk of mass movements. The $200 \mathrm{~m}$ long transverse section has electrodes spaced in $2.5 \mathrm{~m}$ intervals, thus resulting in a $30 \mathrm{~m}$ survey. During the data acquisition, the main unit system synchronously and gradually activates the respective electrodes (as per the measurement

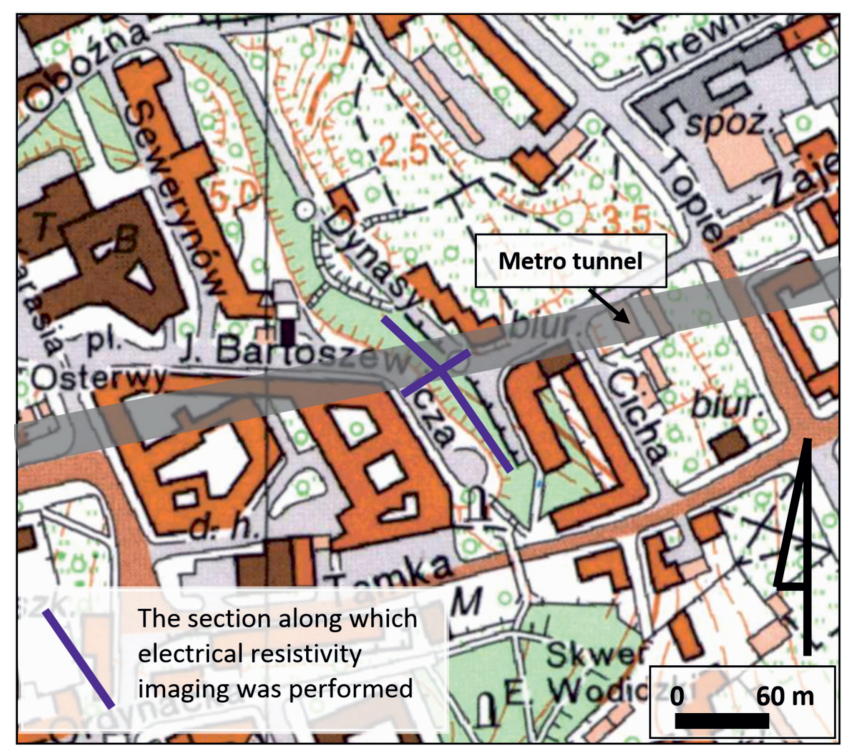

Fig. 3. The location of the geophysical surveying section line.

system selected by the operator). This results in the registration of the resistance distribution along the section with the precision determined by the distance between the electrodes. The study used one of the most popular systems, the gradient system, which provided rapid identification and a good resolution of the cross-section, allowing the identification of each soil layer. In this system, one of the two current electrodes was gradually moved further away, with the position of the other one and of the two measurement electrodes unchanged (Dahlin and Zhou, 2004). Registration accuracy of lateral variability is equal half of the electrodes spacing (Dwain and Butler, 2005). The geophysical surveying was performed using tomography equipment produced by the Abem Company. The source data from the tomography equipment was processed in the RES2Dinv software and used to create a graphical visualization using the Surfer software. 


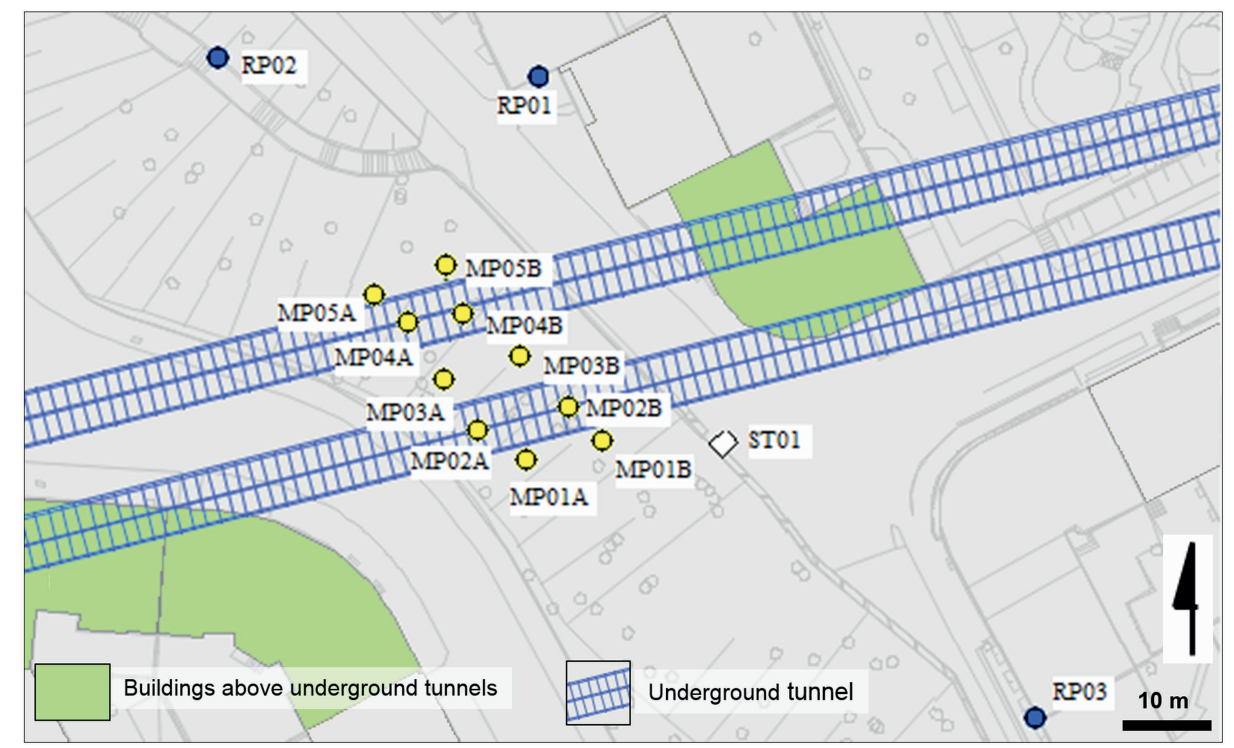

Fig. 4. General location map of the tachymetric site, the measurement points and the connection to the control and measurement network (MP - measurement points, RP - reference points, ST - site), (ddsmonitoring.com)

\section{Surveying - precision total station}

Issues relating to the measurement of terrain surface and facilities displacements were presented in PN-N-02211 (2000) and the GUGiK guidelines G3.1-2007. Additionally, issues associated with land surveying of displacements in urban environment like Warsaw metropolis were described in Woźniak (1999); Woźniak and Żaczek-Peplińska (2014). A detailed description of the theoretical basis with examples of calculation for determining displacement of measurement points can be found in papers by Lazzarini (1977) as well as Prószyński and Kwaśniak (2006). The use of high-precision total stations for measurements in the study of displacements and conditions of this work was presented in the paper of Woźniak (2005).

In order to verify the results of geophysical surveying concerning the identification of the landslide surface, the total station-assisted surveying was used. A precision Leica TM30 total station was selected for conducting the measurements. The selected technique determined the size of the displacements of a group of the controlled points, stabilized shallow in the ground $(0.3-0.5 \mathrm{~m}$ below terrain surface). In order to evaluate the behavior of the soil in the tunnel construction area as terrain surface changes, two transverse sections of controlled points on the scarp were selected in relation to the underground tunnel routes, represented by the 5 analyzed points on each of them (Fig. 4). The distance between both sections was between $8-10 \mathrm{~m}$. The measurements of controlled points enabled determining three spatial components DX, DY and DZ in the local Warsaw coordinate system - the Warszawa'75 coordinate system.

The designed control network, apart from the controlled points, included also the sites for the apparatus (total station) and a group of points constituting a reference system (reference points RP01, RP02, RP03) located outside the zone of direct impact of the construction during the monitoring of displacements (Fig. 4). The internal consistency and constancy of reference points were tested in earlier works with use of classical geodetic techniques and satellite surveys (Woźniak, 2007).

The measurements began with the designation of coordinates of all points of the control network in relation to the local coordinate system based on the geodetic control network of the area. All observations related to the reference and control points were equalized using the method of least squares, and thus obtaining the aligned $\mathrm{x}, \mathrm{y}$ and $\mathrm{z}$ values. These were considered as baseline values for further determination of the displacements.

The free-station technique was used to conduct the measurement; performed from an unsterilized site (ST01) based on spatial resection performed each time relative to the reference points (RP01, RP02, RP03). Figure 4 presents the field situation with controlled and reference points. The reference procedure was carried out using the free-station sub-application in the instrument, which allowed to determine the current coordinates of the site and the orientation of the graduated circle of the instrument. The overdetermination of solving the task of spatial resection allowed not only to determine the site parameters, but also to verify the stability of reference points between the observation cycles. The next step was the determination of the current coordinates of the controlled points (MP01; MP05A; MP01B; MP05B) by means of the radial survey in successive observation cycles, while using the spatial solution related to trigonometric leveling. As a result, the current values of spatial coordinates in a single coordinate system were acquired.

The used procedure of connecting to the reference points was combined with an analysis of the mean error in the determination of the site's position and spatial orientation. The reports from the course of the resection according to the Leica TM30 software indicate stability of the points used by the authors to connect and reference the displacement determination results. When using a number of points of reference and surveying observations for connecting and orientating, a highly overdetermined system is obtained, thus ensuring adequate control of quality as regards determining the position 
of the site. In the traditional leveling process, angular and linear observations, including the identification of the stability of points, should be performed. This procedure could greatly extend the process of measuring and determining the displacements, without noticeable precision effects. The indicated position and orientation of the instrument is the basis for determining the current coordinates of all the controlled points in a given observation cycle.

During the analysis of the results of total station observations of the monitored object (the surface of the Warsaw Scarp), it is important to have information on the obtained accuracy of the surveying results. The so-called mean error $\left(\mathrm{m}_{\mathrm{p}}\right)$ of the point position may be adapted as a parameter describing the accuracy of determining the horizontal position of the point, defined according to the following formula:

$$
\mathrm{m}_{\mathrm{p} 2}=\sigma_{\text {Easting2 }}+\sigma_{\text {Northing2 }}[\mathrm{mm}] \text {; }
$$

where:

$\sigma_{\text {óEasting }}, \sigma_{\text {Northing }}-$ mean error of the $\mathrm{X}$ and $\mathrm{Y}$ coordinate, respectively.

For the two observation series conducted in late 2013 for the controlled points, the resulting mean errors were recorded in the report automatically generated by the standard software of the TM30 instrument. The obtained results permitted to determine the position error of the determined measurement points $\left(\mathrm{m}_{\mathrm{p}}\right)$. A mean error of determining the position of the group of the controlled points in the range between 0.6 and $1.3 \mathrm{~mm}$ was obtained in the conducted surveying.

\section{RESULTS AND DISCUSSION}

As a result of the ERI prospection we obtain two perpendicular resistivity sections of the scarp. The Figure 5 shows the distribution of the electrical resistivity of the soil in the parallel section to underground line, with clearly visible boundaries of areas with different geoelectrical properties. This ERI prospection section was made in the line of archival geological cross-section (Fig. 2). Therefore, the continuity of shallow soil layer on the scarp could be analyzed. Based on archival section the interpretation of resistivity sections was made. There are two distinguishable complexes along with the underground tunnels:

- complex I: it is located across the whole scarp. In Figure

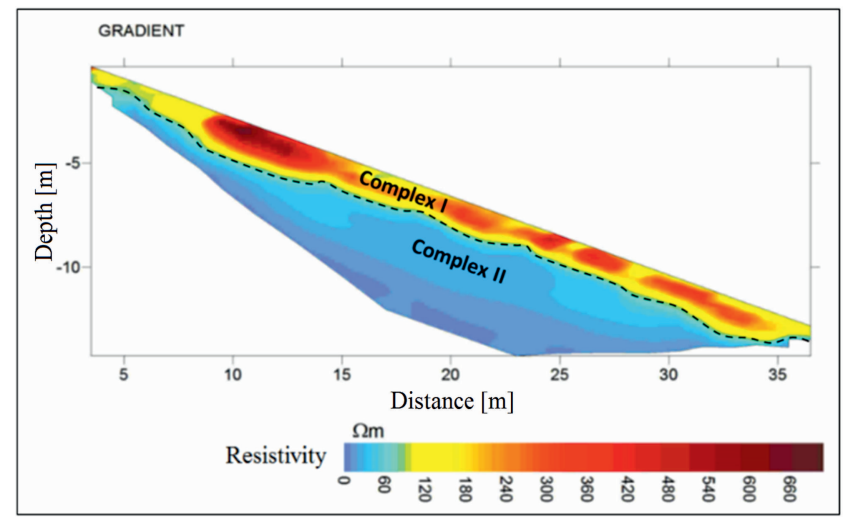

Fig. 5. The results of soil analyses using electrical resistivity imaging, performed longitudinally on the scarp (along the profile on Fig. 3).

5 this complex has resistivity between $120 \Omega \mathrm{m}$ and $600 \Omega \mathrm{m}$, with an average thickness in the electrical resistivity crosssection of approx. $3 \mathrm{~m}$. Following a correlation with the historical data, the interpreted soil was named as sand or clayey sand with elevated humidity (anthropogenic soil: madeground);

- complex II: underlying firs complex. It is minimum 6-7 $\mathrm{m}$ below scarp surface. In Figure 5 characterized by the following resistivity: $5 \Omega \mathrm{m}-70 \Omega \mathrm{m}$. Such resistances indicate cohesive soils, like colluvium sandy clay.

Interpreting perpendicular section to scarp extension it should be noted that the geophysical image of the study area does not contain loosening soil zones, which could indicate slip surface.

In the case of a cross-section perpendicular to the extent of the scarp (Fig. 7), the conducted analyses provided a not clear image. In this case, resistivity image is distorted, due to the presence of metal elements, electrical wires and empty space inside tunnels in the underground line. The reliable information is related to confirmation of the variation of geological deposits and presence of the underground tunnels in these cross-sections. The probable interpretation of this section, based on archival cross-section (Fig. 2) is presented below. In such prospection condition, exact interpretation of soil types and continuity of complex is precluded.

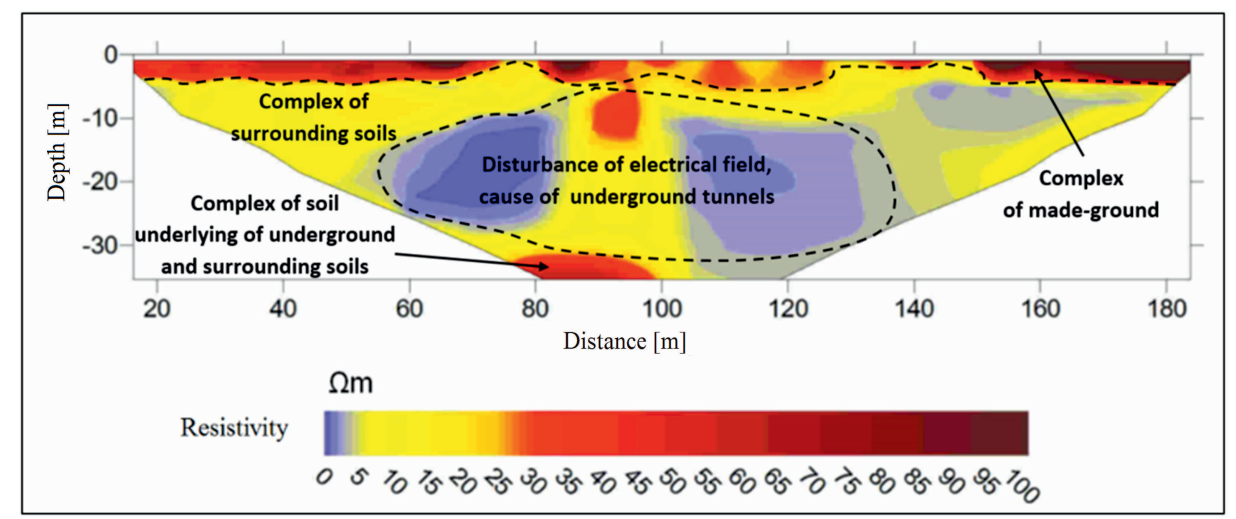

Fig. 6. The results of the ERI prospection, performed parallel to the scarp foot extension and perpendicular to the underground tunnels (along the profile on Fig. 3) 


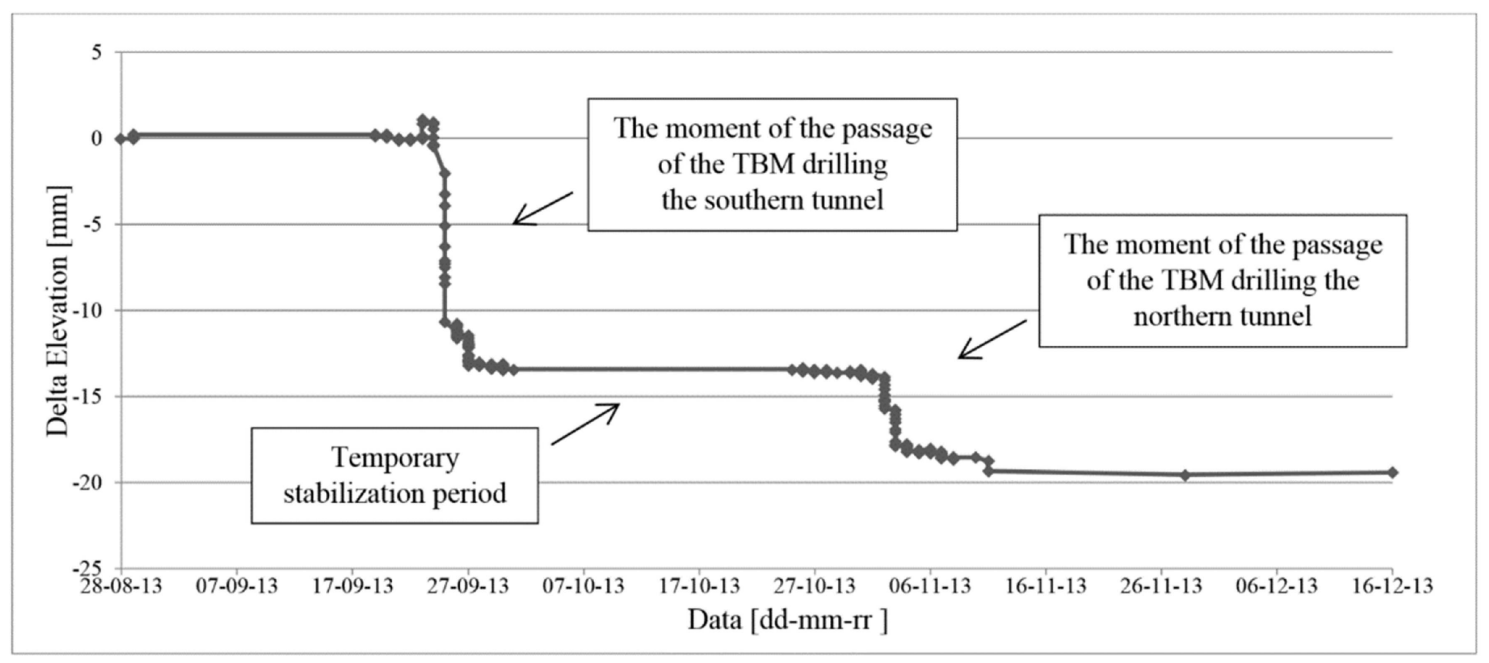

Fig. 7. Vertical displacements as a function of time for the controlled point MP01. The important moment of underground construction.

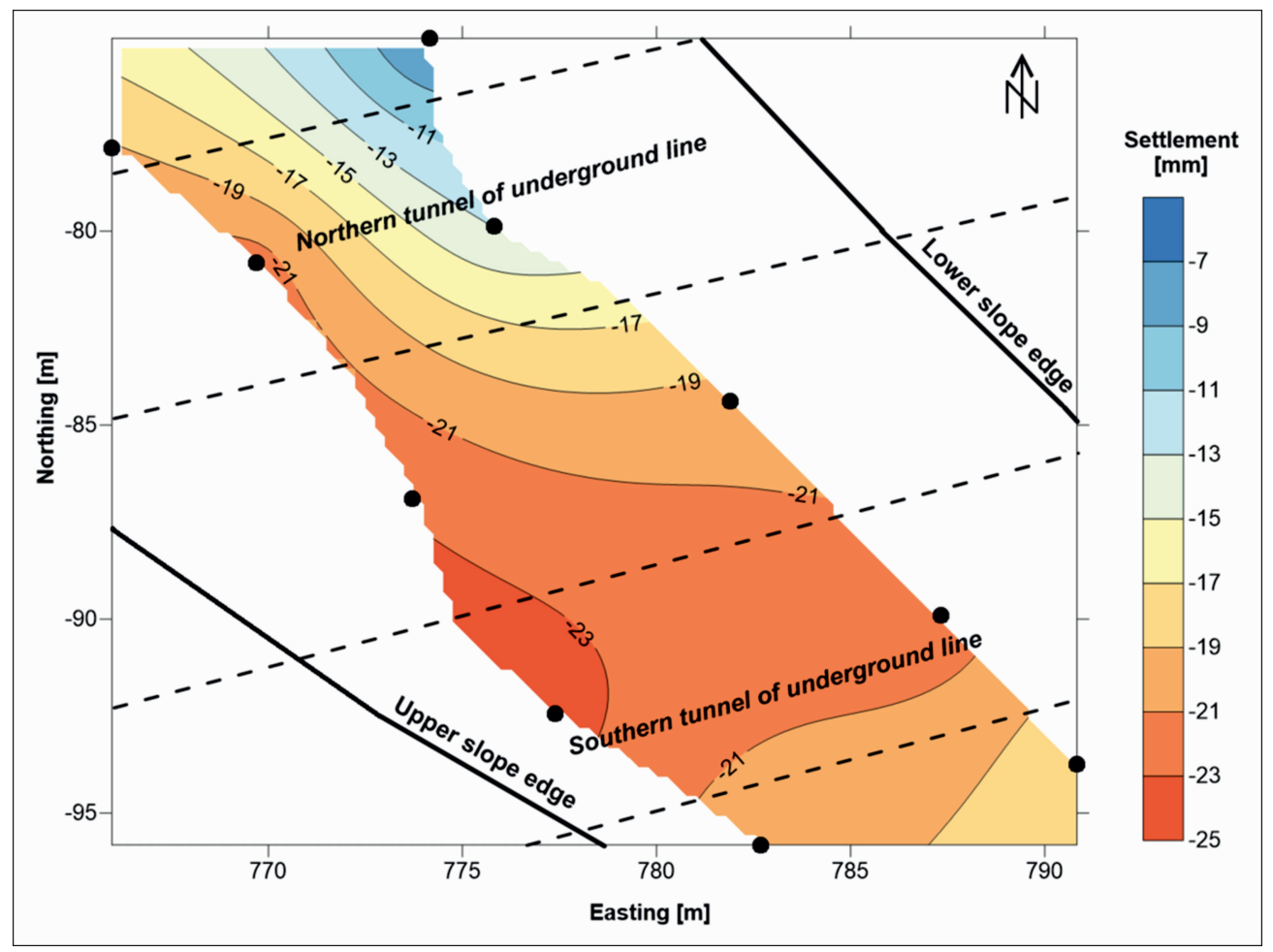

Fig. 8. Cumulative vertical displacements at the end of the monitoring period for the analyzed section of the scarp.

\section{Surveying results}

In order to analyze the impact of the underground construction, the historical results of measurements made by the underground contractor were used before starting the construction, during its course and after its completion. The measurements were also made following the construction of the underground tunnels in order to verify the results of the determination of displacements, and they were added to the charts presented in Fig. 7. The chart showing vertical displacement of a sample controlled point MP01 as a function of time (Fig. 7) clearly shows periods of stability of the results interrupted by sudden increases in the value of the displacements. The first increase in displacement within the analyzed area is caused by the passage of the cutting shield of the TBM drilling the southern tunnel between 24 Sep 2013 and 26 Sep 2013. This change amounted to $-13 \mathrm{~mm}$. After this period, stabilization of the analyzed object and of the displacement value was in effect until the time of the passage of the second TBM drilling the northern tunnel. The TBM was in the area under study between 01 Nov 2013 and 03 Nov 2013, which led to an increase in displacements up to $-19 \mathrm{~mm}$. The character of the observed terrain displacements shows quasi-elastic behavior, which inhibition is due to both the schedule of earthworks, as well as, the delayed reaction of soil massive (Potts and Zdravković, 2001; Kuszyk and Siemińska-Lewandowska, 2009). 
Table 1

Subsidence for selected controlled points

\begin{tabular}{|c|c|c|c|}
\hline Point name & $\begin{array}{c}\text { Northing data } \\
\mathrm{X}[\mathrm{m}]\end{array}$ & $\begin{array}{c}\text { Easting data } \\
\mathrm{Y}[\mathrm{m}]\end{array}$ & $\begin{array}{c}\text { Subsidence } \\
\Delta \mathrm{z}[\mathrm{mm}]\end{array}$ \\
\hline MP01A & -95.8072 & 782.6908 & -19.43 \\
\hline MP02A & -92.4173 & 777.4073 & -23.76 \\
\hline MP03A & -86.8925 & 773.7317 & -22.72 \\
\hline MP04A & -80.8163 & 769.7007 & -21.99 \\
\hline MP05A & -77.8713 & 765.9785 & -19.12 \\
\hline MP01B & -93.7303 & 790.8351 & -17.42 \\
\hline MP02B & -89.9010 & 787.3268 & -22.37 \\
\hline MP03B & -84.3757 & 781.8970 & -19.72 \\
\hline MP04B & -79.8821 & 775.8274 & -12.95 \\
\hline MP05B & -75.0309 & 774.1595 & -6.68 \\
\hline
\end{tabular}

Table 2

Characteristic moments of underground construction associated with coordinates of the representative controlled point MP01A

\begin{tabular}{|c|c|c|c|c|}
\hline $\begin{array}{c}\text { No. of } \\
\text { stage }\end{array}$ & $\begin{array}{c}\text { Description of the mea- } \\
\text { surement performed }\end{array}$ & Date & East [m] & North [m] \\
\hline 0 & Zero measurement & $28-08-2013$ & 782.6879 & -95.8197 \\
\hline 1 & $\begin{array}{c}\text { Measurement before the } \\
\text { passage of the first TBM }\end{array}$ & $21-09-2013$ & 782.6885 & -95.8199 \\
\hline 2 & $\begin{array}{c}\text { Soon after the passage of } \\
\text { the first TBM }\end{array}$ & $29-09-2013$ & 782.6908 & -95.8103 \\
\hline 3 & $\begin{array}{c}\text { Measurement before the } \\
\text { passage of the second } \\
\text { TBM }\end{array}$ & $26-10-2013$ & 782.6906 & -95.8106 \\
\hline 5 & $\begin{array}{c}\text { Soon after the passage of } \\
\text { the second TBM }\end{array}$ & $8-11-2013$ & 782.6903 & -95.8074 \\
\hline 5 & $\begin{array}{c}\text { Own as-built measure- } \\
\text { ment survey }\end{array}$ & $16-12-2013$ & 782.6908 & -95.8072 \\
\hline
\end{tabular}

The Figure 8 below presents the cumulative vertical displacements (settlement) of the controlled points on the scarp, showing that the largest subsidence occurred in the southwestern part of the monitored area. The 3-dimensional counter map was elaborated with the use of Surfer v.10 software, by gridding method named kriging.

Table 1 contains the initial coordinates of the controlled points and summary values of subsidence $z$ from beginning of observations to its end (16 Dec 2013).

The table below describes the key moments in the progress of the investment and the changes in the XY position of the MP01 point. It is worth noting that the threshold horizontal or vertical displacement values adopted by the underground contractor, according to their observation, were $15 \mathrm{~mm}$ for an alert state and $20 \mathrm{~mm}$ for an emergency. When these values were approached, construction work was suspended and the changes in the displacement values were being observed. If there had been no negative impact on the environment (e.g., fracturing), the emergency values would have been increased by the underground designers.

Figure 9 shows horizontal displacements of one of the controlled points. The other points move in a similar manner. The presented chart shows cumulative displacements between the important stages of the investment. We can clearly

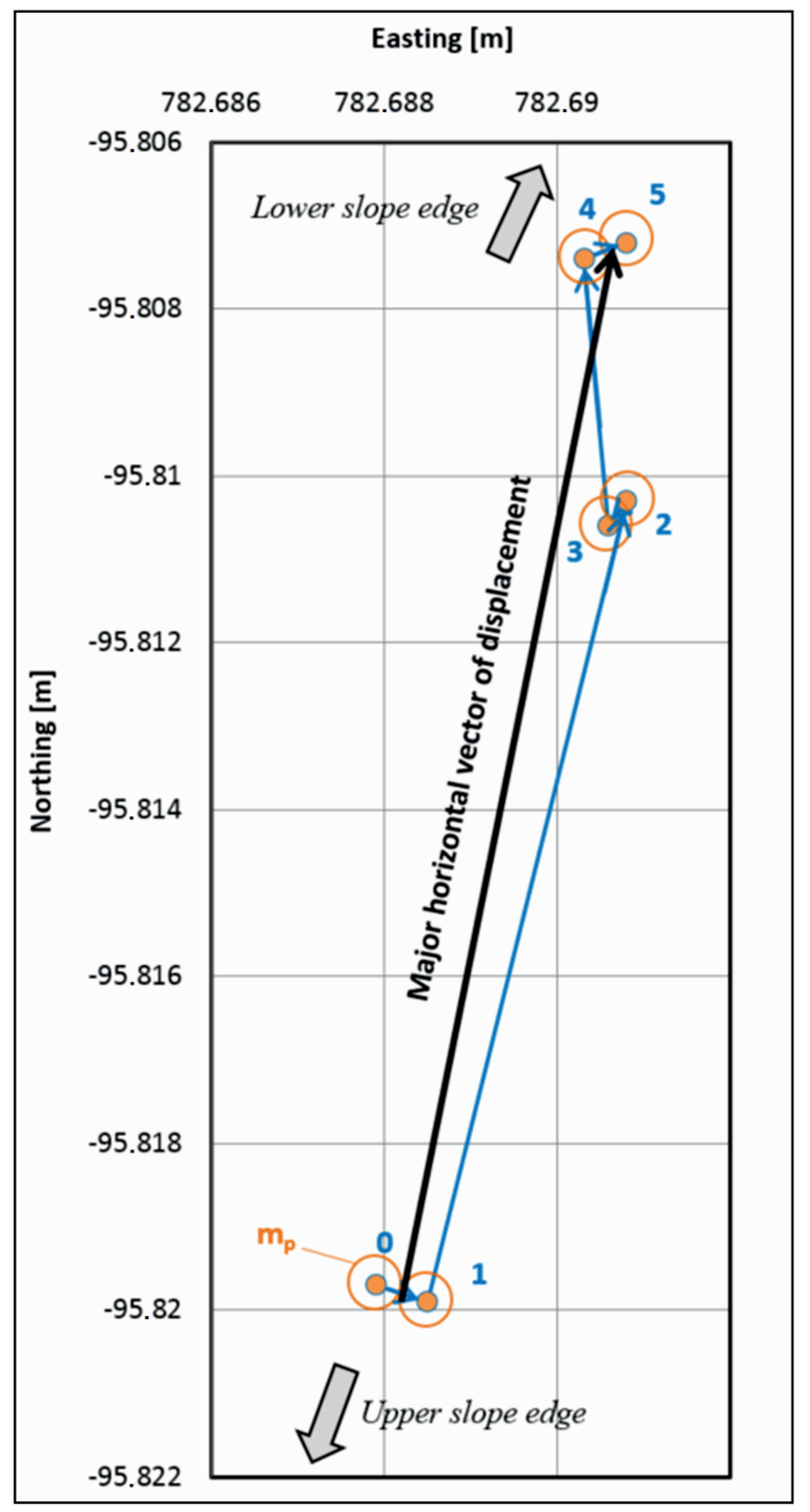

Fig. 9. The horizontal vectors of displacements of controlled point MP01A located on Warsaw Scarp, at different characteristic underground construction stages (No. of stage in blue, the description of stage in Tab. 2).

see the impact of the passage of the first TBM on the monitored section of the scarp, as an increase in displacements amounting to approx. $7 \mathrm{~mm}$. The passage of the second TBM was followed by a further displacement of approx. $6 \mathrm{~mm}$. The observed displacements are directed towards the north-east. The last measurements clearly show that the displacements towards the incline of the scarp stopped.

\section{CONCLUSIONS}

Summarizing the results of the analyses, the question regarding the impact of building the underground tunnels on the Warsaw Scarp at Dynasy Street No. 6, called into question in the subject of the paper, can be answered as follows: the impact is noticeable by present deformations of the scarp, although small enough not to pose a threat to the stability and 
the nearby structures. Total station measurements of points located on the Warsaw Scarp enable calculation of deformation field and displacement vectors of terrain surface above the underground tunnels. In the case of the ERI prospection, despite of the difficult test conditions, the continuity of soil complex up to approx. $6 \mathrm{~m}$ below scarp surface were verified. The assessment of the impact of the second underground line construction on the Warsaw Scarp indicates high usefulness of two used combined methods, which enable an extensive and reliable analysis of implementing the investment in complex urban conditions.

\section{Acknowledgments}

Authors would like to thank Reviewers for their valuable comments that contributed to the improvement of this work. This work was supported by the University of Warsaw Faculty of Geology (contract No. DSM 113232).

\section{REFERENCES}

Bajda, M., Falkowski, T., 2014. Geotechnical tests for estimation of geological conditions of the escarpment zone of "Skarpa Warszawska" in the vicinity of Tamka Street. Landform Analysis $26,77-84$.

Butler, D.K., 2005. Near-Surface Geophysics. Society of Exploration Geophysicists, Tulsa.

Dahlin, T., Zhou, B., 2004. A numerical comparison of 2D resistivity imaging with 10 electrode arrays. Geophysical Prospecting 52, 379-398.

Duncan, J.M., Wright, S.G., 2005. Soil strength and slope stability. John Wiley \& Sons, Hoboken, N.J.

GUGiK, 2007. Technical guidelines G-3.1: Measurements and develop execution (Wytyczne techniczne G-3.1: Pomiary i opracowania realizacyjne). Warszawa (in Polish).

ILF Consulting Engineers Polska Sp. z o. o., 2010. Monitoring project, description of the object and environmental monitoring system for the central part of the Warsaw underground II line, executed by surveying techniques, geotechnical techniques and direct observations (Projekt monitoring, opis systemu monitoringu obiektowego i środowiskowego dla centralnego odcinka II linii metra w Warszawie, realizowanego technikami geodezyjnymi, geotechnicznymi i obserwacjami bezpośrednimi). Astaldi S.p.A., Gulermak, PBDiM Sp. z o.o., Warszawa (in Polish).

Kaczmarek, Ł., Mieszkowski, R., Kołpaczyński, M., Pacanowski, G., 2015. Application of electrical resistivity tomography (ERT) in the investigation of Quaternary landslide zones, based on the selected regions of Płock slope. Studia Quaternaria 31 (2), 101-107. DOI: 10.2478/squa-2014-0010

Kowalczyk, S., Mieszkowski, R., Pacanowski, G., 2014. The stability evaluation of Warsaw slope selected pieces based on Electrical Resistivity Tomography survey (ERT) (Ocena stateczności wybranych fragmentów skarpy warszawskiej w świetle badań geofizycznych metodą tomografii elektrooporowej). Przegląd Geologiczny 62 (10/2), 634-640 (in Polish with English summary).

Kuszyk, R., Siemińska-Lewandowska, A., 2009. Evaluation of the subsidence progress above the metro tunnel created by Tunnel Boring Machine (Ocena rozwoju niecki osiadań nad tunelem drążonym tarczą zmechanizowaną). Gór. Geoinżyn. 33 (3/1), 229-237 (in Polish).

Lazzarini, T., (ed.) 1977. Surveying of buildings and their surroundings displacements (Geodezyjne pomiary przemieszczeń budowli i ich otoczenia). Państw. Przeds. Wydaw. Kar- tograficznych, Warszawa (in Polish).

Lejzerowicz, A., Kowalczyk, S., Wysocka, A., 2014. The usefulness of ground-penetrating radar images for the research of a large sand-bed braided river: case study from the Vistula River (central Poland). Geologos 20 (1), 35-47.

Loke, M.H., 2000. Electrical imaging surveys for environmental and engineering studies. Wyd. Abem, Stokholm.

Loke, M.H., 2012. Tutorial: 2-D and 3-D electrical imaging surveys. Wyd. Abem, Stokholm.

Perrone, A., Lapenna, V., Piscitelli, S., 2014. Electrical resistivity tomography technique for landslide investigation: A review. Earth-Science Reviews 135, 65-82.

PN-N-02211. 2000. Geodesy. Survey determining of displacements (Geodezja. Geodezyjne wyznaczenie przemieszczeń). Warszawa (in Polish).

Potts, D.M., Zdravković, L., 2001. Finite element analysis in geotechnical engineering. Thomas Telford, London.

Prószyński, W., Kwaśniak, M., 2006. Basics of geodetic determination of displacements (Podstawy geodezyjnego wyznaczania przemieszczeń). Oficyna Wydawnicza Politechniki Warszawskiej, Warszawa (in Polish).

Sarnacka, Z., 1992. Stratigraphy of Quaternary sediments of Warsaw and surroundings (Stratygrafia osadów czwartorzędowych Warszawy i okolic). Wyd. PIG, Warszawa (in Polish).

Tucholka, P., Kiełbasiński, K., Mieszkowski, R., 2008. Tracing seismic Surface waves induced by road traffic in urban environment: example of st. Catherine's church hill in Warsaw. Geologija 50, S79-S84.

Welc, F., Trzciński, J., Kowalczyk, S., Mieszkowski, R., 2013. Geophysical survey (GPR) in West Saqqara (Egypt) preliminary remarks. Studia Quaternaria 30 (2), 99-108.

Woźniak, M., 1999. Geodetic displacement monitoring systems for the construction industry - geodetic monitoring of displacements during the objects erecting in deep trenches (Systemy geodezyjnego monitorowania przemieszczeń dla potrzeb budownictwa - Geodezyjny monitoring przemieszczeń podczas wznoszenia obiektów w głębokich wykopach). Opracowanie monograficzne Politechnika Warszawska, Warszawa (in Polish).

Woźniak, M., 2005. Geodetic measurement systems in monitoring of displacements. Reports of Geodesy 3 (74), 125-131.

Woźniak, M., 2007. Development of the methodology procedure for the establishment of monitoring systems for displacements of selected consruction components (Opracowanie metodyki postępowania przy zakładaniu systemów monitorujących przemieszczenia wybranych elementów konstrukcyjnych). Ekspertyza, Warszawa (in Polish).

Woźniak, M., Żaczek-Peplińska, J., 2014. Measurements of displacements performed in deep excavations conditions (Pomiary przemieszczeń realizowane $\mathrm{w}$ warunkach głębokich wykopów). Tom VI Seria Wydawnicza: Monografie Wydziału Inżynierii Lądowej, Oficyna Wydawnicza Politechniki Warszawskiej, Warszawa (in Polish).

Wysokiński, L., 1999. The Warsaw Slope in the Śródmieście district (from al. Jerozolimskie to the Sanguszki St.) (Warszawska skarpa śródmiejska (od Al. Jerozolimskich do ul. Sanguszki)). Drukarnia Piotra Włodarskiego, Warszawa (in Polish).

Wysokiński, L., 2013. The expertise for the determination of realization conditioning of D13 tunnels construction by Tunnel Boring Machines TBM under the Warsaw Slope during the construction of the central part of the II underground line in Warsaw (Ekspertyza dotycząca określenia uwarunkowań realizacyjnych przy budowie tuneli szlakowych D13 tarczami zmechanizowanymi TBM pod Skarpą Warszawską podczas budowy odcinka centralnego II linii metra w Warszawie). Warszawa (in Polish). 